\title{
Socio-environmental factors and depression among secondary school children in Dhaka city
}

\author{
Mekhala Sarkar, ${ }^{1}$ Susmita Roy, ${ }^{2}$ Mohammad Muntasir Maruf, ${ }^{3}$ Md Golam Rabbani ${ }^{4}$ \\ ${ }^{1}$ Associate Professor of Psychiatry, National Institute of Mental Health (NIMH), Sher-E-Bangla Nagar, Dhaka, Bangladesh; ${ }^{2}$ Associate \\ Professor, Department of Psychiatry, Jalalabad Ragib Rabeya Medical College, Sylhet, Bangladesh; ${ }^{3}$ Assistant Professor, Department of \\ Psychiatry, Shaheed M. Monsur Ali Medical College, Sirajganj, Bangladesh; ${ }^{4}$ Professor, Department of Psychiatry, Popular Medical College, \\ Dhaka, Bangladesh.
}

$\begin{array}{ll}\text { Article info } & \\ \text { Received } & : \text { 2 June } 2017 \\ \text { Accepted } & : \text { 26 Nov. } 2017 \\ \text { Number of tables } & : 7 \\ \text { Number of figures } & : 11 \\ \text { Number of refs } & : 15\end{array}$

Correspondence

Mekhala Sarkar

E-mail:mekhala_sarkar@yahoo.com

\begin{abstract}
Summary
Depression among children and adolescents has been increasingly recognized as a major public health problem. The objective of the study was to find out socio-environmental factors associated with the presence of depression among secondary school children in Dhaka city. It was a cross-sectional study conducted from November 2008 to October 2009 in two purposively selected schools (one boys' and one girls') of Dhaka city. Simple random sampling was used to collect 144 samples from class VI to class IX. A semi-structured self-administered questionnaire including the translated Bangla version of the Center for Epidemiologic Studies Depression Scale for Children (CES-DC) was used to assess depression. The results showed that, majority of the respondents lived in nuclear family whereas $79.2 \%$ boys and $51.4 \%$ girls had only $1-2$ siblings. The mean number of siblings $(2.19+0.588)$ was higher among the respondents with depression than among the respondents without depression which was statistically significant. In boys' school, emotional bullying by peer group was complained mostly by the students of class VIII (22.2\%) whereas in girls' school, students of class VI $(44.4 \%)$ complained of being bullied emotionally mostly. In this study, those boys (45.5\%) who complained of emotional bullying by their peer group were found as significantly depressed than those who had no such complaints. Proportion of depression was higher among those respondents who had any history of physical or psychiatric illness in their family. The findings of the study emphasized on the importance of the school mental health services.
\end{abstract}

Bang J Psychiatry 2015;29(2):48-52

\section{Introduction}

Mental health conditions in children and adolescents has been of growing concern and depression is one of the most significant mental health problem in this group. ${ }^{1,2}$ Currently, more adolescents are reported to suffer from mental health problems than compared to the past. ${ }^{3}$ Besides, globalization is leading to rapid changes in these socio-cultural systems in low and middle income countries and changing values and expectations of adolescents may influence the risk of mental disorders. ${ }^{4}$ Studies in high income countries have shown that depression, anxiety and substance misuse are relatively common psychosocial health problems during adolescence. 5,6 Depressive episodes in childhood depression are recurrent and may lead to depression in adulthood, if the contributing factors remain unabated. Early depressive vulnerability is a predictive factor for depression in adulthood. ${ }^{7}$ Studies conducted on the prevalence of depression among adolescents have showed that the prevalence ranged from $5 \%$ to $20 \%{ }^{8,9}$ A study in the secondary schools from urban and rural areas in the state of Selangor, Malaysia, found that $10.3 \%$ of the students were much above average in the depression scale. ${ }^{10}$ Studies conducted among child and adolescent patients admitted in a hospital of Bangladesh, showed that the proportion of depression among overall psychiatric morbidity was $2.46 \% .{ }^{11}$ Besides, studies among the outpatients of Bangladeshi children and adolescents found that the proportion of emotional disorders and depressive disorders was $32.5 \%$ and $3.6 \%$ respectively. ${ }^{12,13}$ In another study of Bangladesh, emotional disorder was 3.2\% among all behavioral disorders in primary school children. ${ }^{14}$ Unlike many medical disorders, a majority of adolescent mental disorders represent the extreme end of normal distribution and are multi-factorial in aetiology. ${ }^{15}$ The aetiology of unipolar depressions is complex with evidence for genetic and environmental factors. ${ }^{16}$ Substantial research literatures, mostly from developed countries, suggested a complex socio-ecological framework of risk factors operating in multiple contexts that are central to the lives of 
adolescents, namely, home, school, peer group and neighborhood. ${ }^{17-19}$

Studying the prevalence of mental health problems in adolescents and its associated factors is of vital importance for the planning and implementation of mental health services to this group. In spite of the significance of the issue, the number of related studies is inadequate in Bangladesh. So, considering all relevant findings, this study was aimed to find out the socio-environmental factors which might have influence on the depression among the secondary school children and adolescents in selected schools of Dhaka city.

\section{Materials and methods}

This was a cross-sectional study conducted from November 2008 to October 2009 among 144 school children in two selected public schools in Dhaka city named Dhanmondi Government Boys' High School and Dhanmondi Government Girls' High School. For the convenience of the study one boys' and one girls' school were selected by purposive sampling technique. All secondary school students from class VI to IX and aged less than 18 years were the study population. Simple random sampling was used to collect 144 samples. Considering the effect of stress of Secondary School Certificate (SSC) examination, students of class $X$ and who were on medication for last one month or suffering from any acute or chronic illness from last one week or unable to attend the school on the selected date of data collection had been excluded from the study. A semi-structured questionnaire was developed in English, then translated to Bangla contained questions related to socio-environmental data like religion, family size and type, number of siblings, monthly family expenditures, emotional bullying by the peer group, family history of physical and psychiatric illness etc. Translated Bangla version of the Center for Epidemiologic Studies Depression Scale for Children (CES-DC) was used to assess depressive status. ${ }^{20,21}$ The interviews were held in a peaceful and non-threatening environment. Ethical issues were maintained properly throughout the study. After collecting data, editing was done manually and was analyzed with the help of Statistical Package for the Social Sciences (SPSS) software package version 12. Chi-square tests were done between discrete variables to check for the statistical significant association between different variables. Student's t-test of significance was performed to determine whether an observed difference of the means of continuous variables was significant. The odds ratio (OR) with $95 \%$ confidence interval (CI) for risk factors was calculated taking the least proportionate clinically relevant criteria as reference value. All the tests were two tailed and $p<0.05$ was considered to be statistically significant.

\section{Results}

The results showed that, $94.4 \%$ respondents were Muslim and the rests were Hindu. The difference of proportion of depression between the two different religions was not statistically significant $(p>0.05)$ (Table 1$)$. Total family members of the respondents ranged from 3 to 10 . On average they were living with 4.80 numbers of family members. The mean family size of male respondents was $4.49( \pm 97)$ whereas it was $5.11( \pm 1.44)$ for female respondents. Majority of the respondents for both boys $(79.2 \%)$ and girls $(51.4 \%)$ had only 1 to 2 siblings (Table 2 ) and $85 \%$ of them lived in nuclear family (Figure 1). The Student's t-test showed that there was no significant difference of mean family expenditure among the respondents with or without depression ( $p>0.05)$. The mean number of siblings $(2.19 \pm 588)$ was higher among the respondents with depression than among the respondents without depression which was also statistically significant $(p=0.002)$ (Table 3). There was not much difference between the respondents with regards to depression who live in nuclear and joint family ( $46.8 \%$ vs. $41.2 \%$ ) and this difference was not also statistically significant ( $p>0.05$ ) (Table 4). In boys' school, emotional bullying by peer group was complained mostly by the students of class VIII $(22.2 \%)$ followed by students of class VII (16.7\%). But in girls' school, students of class $\mathrm{VI}$ complained of being bullied emotionally mostly. They comprised $44.4 \%$ of total female study population. No girls of class VIII was found with such a complaint (Table 5).

Table 1: Religion of the respondents and presence of depression $(n=144)$

\begin{tabular}{|c|c|c|c|c|}
\hline \multirow{2}{*}{$\begin{array}{l}\text { Religion of the } \\
\text { respondents }\end{array}$} & \multicolumn{2}{|c|}{ Presence of depression } & \multirow[t]{2}{*}{ Total (\%) } & \multirow{2}{*}{$\begin{array}{c}\text { Test } \\
\text { statistic }\end{array}$} \\
\hline & $\begin{array}{c}\text { Frequency } \\
\text { Yes (\%) }\end{array}$ & $\begin{array}{c}\text { Frequency } \\
\text { No }(\%)\end{array}$ & & \\
\hline Islam & $39(28.7)$ & $97(71.3)$ & $136(94.4)$ & ${ }^{*} \mathrm{P}=.239$ \\
\hline Hindu & $4(50.0)$ & $4(50.0)$ & $8(5.6)$ & \\
\hline
\end{tabular}

*Fisher's exact test was done

Table 2: Family size and number of siblings of the respondents $(n=144)$

\begin{tabular}{|c|c|c|c|c|}
\hline Characteristics & & $\begin{array}{c}\text { Boys } \\
\text { Frequency } \\
(\%) \\
\end{array}$ & $\begin{array}{c}\text { Girls } \\
\text { Frequency } \\
(\%) \\
\end{array}$ & $\begin{array}{c}\text { Total } \\
\text { Frequency } \\
(\%) \\
\end{array}$ \\
\hline Family size & $3-4$ & $44(61.1)$ & $29(40.3)$ & $73(50.7)$ \\
\hline (in number) & $\begin{array}{l}5-6 \\
\geq 7\end{array}$ & $\begin{array}{c}24(33.3) \\
4(5.6)\end{array}$ & $\begin{array}{l}30(41.7) \\
13(18.1)\end{array}$ & $\begin{array}{l}54(37.5) \\
17(11.8)\end{array}$ \\
\hline $\begin{array}{l}\text { Mean (+SD) } \\
\text { (in number); } \\
\text { Range= 3-10 }\end{array}$ & & $\begin{array}{c}4.49 \\
( \pm 97) ; 3-7\end{array}$ & $\begin{array}{c}5.11 \\
( \pm 1.44) ; 3-10\end{array}$ & $\begin{array}{c}4.80 \\
( \pm 1.27)\end{array}$ \\
\hline $\begin{array}{l}\text { Number of } \\
\text { Siblings }\end{array}$ & $\begin{array}{l}1-2 \\
2-4 \\
3-6\end{array}$ & $\begin{array}{c}57(79.2) \\
13(18.1) \\
2(2.8)\end{array}$ & $\begin{array}{l}37(51.4) \\
24(33.3) \\
11(15.3)\end{array}$ & $\begin{array}{l}73(50.7) \\
54(37.5) \\
17(11.8)\end{array}$ \\
\hline
\end{tabular}




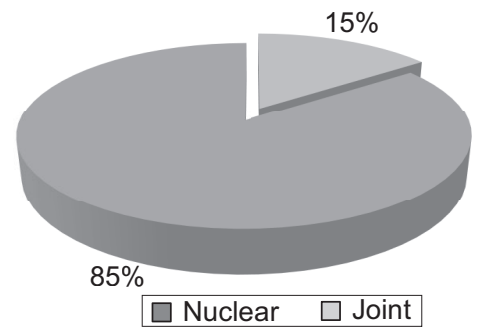

Figure 1: Types of family of the respondents $(n=144)$

In this study, those boys (45.5\%) who complained of emotional bullying by their peer group were found as significantly depressed than those who had no such complaints. Those boys who were emotionally bullied had 4 times increased risk of having depression than who had not such exposure $(\mathrm{OR}=4.81$; C.I. $=1.20-19.17)$. Among girls, 36.8\% respondents were depressed who had emotional bullying and the rest of them $(41.5 \%)$ did not complain anything like this though no statistical significance was found (Table 6). Proportion of depression was higher among those respondents who had any history of physical or psychiatric illness in the family though statistical test failed to find any significant association $(p<0.05)$ (Table 7).

Table 3: Monthly family expenditure and total number of siblings with depression ( $n=144)$

\begin{tabular}{|c|c|c|c|c|c|}
\hline Characteristics & $\begin{array}{l}\text { Presence of } \\
\text { depression }\end{array}$ & $\begin{array}{c}\text { Number of } \\
\text { respondents }\end{array}$ & Mean & SD & $\begin{array}{c}\text { Test } \\
\text { statistic }\end{array}$ \\
\hline Monthly family expenditure & Yes & 43 & 22313.95 & +12227.031 & $t_{(142)}=-1.178 p=.241$ \\
\hline (in taka) & No & 101 & 25217.82 & +14055.322 & \\
\hline \multirow[t]{2}{*}{ Total number of siblings } & Yes & 43 & 2.19 & +.588 & $t_{(141)}=-3.098 p=0.002$ \\
\hline & No & 101 & 2.66 & +1.259 & \\
\hline
\end{tabular}

Table 4: Types of family of the respondents and presence of depression $(n=144)$

\begin{tabular}{|c|c|c|c|c|}
\hline \multirow[t]{2}{*}{ Types of family } & \multicolumn{2}{|c|}{ Presence of depression } & \multirow[t]{2}{*}{ Total $(\%)$} & \multirow[t]{2}{*}{ Test statistic } \\
\hline & $\begin{array}{c}\text { Yes } \\
\text { Frequency (\%) } \\
\end{array}$ & $\begin{array}{c}\text { No } \\
\text { Frequency (\%) }\end{array}$ & & \\
\hline Nuclear & $73(46.8)$ & $83(53.2)$ & $156(75.4)$ & $\chi_{(1)}^{2}=0.486 p=0.256$ \\
\hline Joint & $21(41.2)$ & $30(58.8)$ & $51(24.6)$ & \\
\hline
\end{tabular}

Table 5: Presence of emotional bullying by the peer groups $(n=144)$

\begin{tabular}{lllllll}
\hline Characteristics & \multicolumn{2}{c}{ Boys (Percentage) } & & \multicolumn{2}{c}{ Girls (Percentage) } \\
\cline { 2 - 3 } \cline { 5 - 6 } & Yes & No & & Yes & No & \\
\hline Presence of emotional & Class VI & 11.1 & & 88.9 & 44.4 & 55.6 \\
bullying by peer groups & Class VII & 16.7 & & 83.3 & 38.9 & 61.1 \\
& Class VIII & 22.2 & & 77.8 & 0 & 100 \\
& Class IX & 11.1 & & 88.9 & 22.2 & 77.8 \\
\hline
\end{tabular}

Table 6: Emotional bullying by peer groups and presence of depression $(n=144)$

\begin{tabular}{|c|c|c|c|c|c|}
\hline \multicolumn{2}{|c|}{ Characteristics } & \multicolumn{2}{|c|}{ Presence of depression } & \multirow[t]{2}{*}{ Total (\%) } & \multirow[t]{2}{*}{ Test statistic } \\
\hline & & Yes (\%) & No $(\%)$ & & \\
\hline \multirow[t]{2}{*}{ Boys } & Yes & $5(45.5)$ & $6(54.5)$ & $11(15.3)$ & $p=.032^{*}$ \\
\hline & No & $9(14.8)$ & $52(85.2)$ & $61(84.7)$ & $\mathrm{OR}=4.81 \mathrm{C} \cdot \mathrm{I}=1.20-19.17$ \\
\hline \multirow[t]{2}{*}{ Girls } & Yes & $7(36.8)$ & $12(63.2)$ & $19(26.4)$ & $\chi_{(1)}^{2}=3.064 p=.722$ \\
\hline & No & $22(41.5)$ & $31(58.5)$ & $53(73.6)$ & \\
\hline
\end{tabular}

${ }^{*}$ Fisher's exact test was done 
Table 7: Family history of physical and psychiatric illness of the respondents and presence of depression ( $n=144)$

\begin{tabular}{|c|c|c|c|c|}
\hline \multirow[t]{2}{*}{ Characteristics } & \multicolumn{2}{|c|}{ Presence of depression } & \multirow[t]{2}{*}{ Total $(\%)$} & \multirow[t]{2}{*}{ Test statistic } \\
\hline & $\begin{array}{c}\text { Yes } \\
\text { Frequency (\%) }\end{array}$ & $\begin{array}{c}\text { No } \\
\text { Frequency (\%) }\end{array}$ & & \\
\hline \multicolumn{5}{|c|}{ Family history of physical illness and depression } \\
\hline Yes & $12(32.4)$ & $25(67.6)$ & $37(25.7)$ & $\chi_{(1)}^{2}=.157 p=0.692$ \\
\hline No & $31(29.0)$ & $76(71.0)$ & $107(74.3)$ & \\
\hline \multicolumn{5}{|c|}{ Family history of psychiatric illness and depression } \\
\hline Yes & $5(38.5)$ & $8(61.5)$ & $13(9.0)$ & $\chi_{(1)}^{2}=.50 p=0.477$ \\
\hline No & $38(29.0)$ & $93(71)$ & $131(91.0)$ & \\
\hline
\end{tabular}

\section{Discussion}

Adolescent depression is related to various demographic, family and school related characteristics. The present study showed that, total family members of the respondents ranged from 3 to 10. On average they were living with 4.80 numbers of family members. The mean family size of male respondents was $4.49( \pm 0.97)$ whereas it was $5.11( \pm 1.44)$ for girls. The mean number of siblings was higher among the respondents with depression $(2.19 \pm 0.588)$ than among the respondents without depression which was statistically significant $(p=.002)$. There was not much difference between the respondents with regards to depression who live in nuclear and joint family $(46.8 \%$ vs. $41.2 \%)$ and this difference was not statistically significant $(p>0.05)$. A few studies from low and middle income countries have identified family structure and relationships, social class, urbanization and school failure as the factors of depression. ${ }^{22}$ Though in major epidemiological studies, prevalence of depression was found to be much higher $(32.4 \%)$ among adolescents of low socio-economic status, the present study showed no significant difference of mean family expenditure among the respondents with or without depression ( $p>0.05) .{ }^{23,24}$ However, to see the economic condition, family expenditure was assessed despite family income considering the fact that respondents give more reliable answer in later variable. But this factor was not significantly associated with depression among children and adolescents though study done by Ramil M et al. (2008) showed the opposite result. ${ }^{25}$ This difference in picture could be explained by the fact that later study was done in both rural and urban settings where there was much socioeconomic diversities whilst in this study, respondents' families had somewhat uniform economic background. Nonetheless, the study done among Korean children by Shin M Y et al. (2008) did not also find out any association in this regard. ${ }^{26}$ In the present study, the number of siblings of the respondents showed to have significant influence on the onset of depression. The study found that those respondents who had more number of siblings were significantly more depressed which was also in agreement with a previous study. ${ }^{25}$ However, other socio-demographic characteristics like religion, family type, and family sizes were not found statistically significant with depression among secondary school children.

One of the most distinctive features of adolescence is the rise in the importance of peers. The level of the support an adolescent perceives from his/her relationships with friends may affect whether he/she will suffer from depression. Results of the present study support this idea. Even though peers gain significance during adolescence, family also remains important. The level of the support an adolescent perceives from his/her relationships with friends and family may affect whether he/she will suffer from depression. Findings of the present study confirm this view. This study found that among boys, both emotional bullying by peer group and history of physical abuse by parents had significant influence on presence of depression which was also consistent with the findings of some previous studies. ${ }^{25,27,28}$ Here, the above mentioned factors were not found significant among girls in presence of depression. So, the difference in picture between girls and boys could be explained by the fact that girls in our country could have better adjustment and coping ability with social adversities. In current study, proportion of depression was higher among those respondents who had any history of physical or psychiatric illness in the family though statistical test failed to find any significant association $(p<0.05)$. Empirical studies put forth that depression is related to psychiatric disorder in a family member. ${ }^{29}$

\section{Conclusion}

The overall finding of the study indicates that possibility of depression is significantly present in school going child population. As depression has significant impact on child development and other aspects of life, this issue needs to be addressed. This study gives us baseline information about possibility of depression and offers important guidelines for future work in this area. Hence, a broad based, multi-centered epidemiological study can confirm the actual magnitude of 
the disorder and associated risk factors, so that proper planning of the school mental health service could be devised appropriately by our policymakers.

\section{References}

1. Hamrin V, Pachler MC. Child and adolescent depression: review of the latest evidence-based treatments. J Psychosoc Nurse 2005;43:54-63.

2. Dopheide JA. Recognizing and treating depression in children and adolescents. Am J Health-Syst Pharm 2006;63:233-43.

3. Collishaw S, Maughan B, Goodman R, Pickles A. Time trends in adolescent mental health. J Child Psychol Psychiatry 2004;45:1350-62.

4. Timimi S. Effect of globalisation on children's mental health. BMJ 2005;331:37-9.

5. Elster AB, Marcell AV. Health care of adolescent males: overview, rationale, and recommendations. Adolesc Med 2003;14: 525-40.

6. Roberts RE, Attkisson CC, Rosenblatt A. Prevalence of psychopathology among children and adolescents. Am J Psychiatry 1998;155(6):715-25.

7. Lewinsohn PM, Roberts RE, Seeley JR, Rohde P, Gotlib IH, Hops H. Adolescent psychopathology: II. Psychosocial risk factors for depression. J Abnorm Psychol 1994;103(2):302-15.

8. Saluja G, lachan R, Scheidt PC, Overpeck MD, Sun W, Giedd JN. Prevalence of and risk factors for depressive symptoms among young adolescents. Arch Pediatr Adolesc Med 2004;158(8): 760-5.

9. Melnyk BM, Brown HE, Jones DC, Kreipe R, Novak J. Improving the mental/psychosocial health of US children and adolescents: Outcomes and implementation strategies from the national KySS Summit. J Pediatr Health Care 2003;17:1-24.

10. World Health Organization. International statistical classification of diseases and related health problems. $10^{\text {th }}$ rev. Geneva: World Health Organization; 1992.

11. Alam MF, Hasan N, Ali M, Azad MC, Bashar K, Akter F, et al. Multiaxial diagnosis of child and adolescent psychiatric disorders in inpatient department of National Institute of Mental Health, Dhaka. Bang J Psychiatry 2004;18(2):55-65.

12. Mullick MSI, Khanam M, Islam H. Psychiatric morbidity of outpatient children in institute of mental health and research. Bang J Psychiatry 1995;7(1):4-8.

13. Sarkar M, Khan MZR, FirozAHM, Rabbani MG, Alam MF. Pattern of psychiatric morbidity among children and adolescents attending child guidance clinic of National Institute of Mental Health, Dhaka. Bang J Psychiatry 2008;22(1):11-21.

14. Rabbani MG, Hossain MM. Behaviour disorder in urban primary school in Dhaka, Bangladesh. Pub Health 1999;113(5):233-6.
15. Hoare P, Will D, Wrate R. Forfar and Arneil's textbook of pediatrics. $5^{\text {th }}$ ed. Edinburgh: Churchill Livingstone; 1998.

16. Kendler KS, Gardner CO, Prescott CA. Toward a comprehensive developmental model for major depression in women. Am J Psychiatry 2002;159(7):1133-45.

17. Beam MR, Gil-Rivas V, Greenberger E, Chen C. Adolescent problem behavior and depressed mood risk and protection within and across social contexts. J Youth Adolescence 2002;31:343-57.

18. Boys A, Farrell M, Taylor C, Marsden J, Goodman R, Brugha T, et al. Psychiatric morbidity and substance use in young people aged 13-15 years: results from the child and adolescent survey of mental health. Br J Psychiatry 2003;182:509-17.

19. Patel V, Flisher A, Hetrick S, McGorry P. Mental health of young people: a global public-health challenge. Lancet 2007;369(9569):1302-13.

20. Kovacs M. Presentation and course of major depressive disorder during childhood and later years of the lifespan. J Am Acad Child Adolesc Psychiatry 1996;35:705-15.

21. Kolvin I. Clinical phenomenology and classification. Cambridge: Cambridge University Press; 1995.

22. Weissman MM, Wickramaratne $P$, Nomura $Y$, Warner $V$, Verdeli $\mathrm{H}$, Pilowsky DJ, et al. Families at high and low risk for depression: a 3-generation study. Arch Gen Psychiatry 2005;62(1):29-36.

23. Kessler RC, Walters EE. Epidemiology of DSM-III-R major depression and minor depression among adolescents in the National Comorbidity Survey. Depress Anxiety 1998;7(1):3-14.

24. Velez CN, Johnson J, Cohen P. A longitudinal analysis of selected risk factors for childhood psychopathology. J Am Acad Child Adolesc Psychiatry 1989;28:861-4.

25. Ramli M, Adlina S, Suthahar A, EdariahAB, Ariff FM, Narimah $\mathrm{AHH}$, et al. Depression among secondary school students: a comparison between urban and rural populations in a Malaysian community. Hg Kg J Psychiatry 2008;18(2):55-61.

26. Shin YM, Cho H, Lim KY, Cho SM. Predictors of self-reported depression in Korean children 9 to 12 years of age. Yonsei Med J 2008;49(1):37-45.

27. Eskin M, Ertekin K, Harlak H, Dereboy C. Prevalence and factors related to depression in high school students. Turk Psikiyatri Derg 2008;19(4):382-9.

28. Reinherz HZ, Paradis AD, Giaconia RM, Stashwick CK, Fitzmaurice G. Childhood and adolescent predictors of major depression in the transition to adulthood. Am J Psychiatry 2003;160(12):2141-7.

29. Egger HL, Angold A. Common emotional and behavioral disorders in preschool children: presentation, nosology, and epidemiology. J Child Psychol Psychiatry 2006;47(3-4):313-37. 